\title{
THE CHANGES IN THE USAGE OF AGRICULTURAL LAND IN EASTERN REGION OF REPUBLIC OF MACEDONIA BETWEEN 1991 AND 2030
}

\author{
Mile Peshevski ${ }^{1}$,Zoran Milovancevic ${ }^{2}$
}

\section{Summary}

This paper will present the analysis of the degree of changes in the usage of agricultural land in Eastern region of Republic of Macedonia. The basis for this analysis is statistical data for previous 23 years (1991 - 2013). The forecast presented here will encompass period of following 17 years, $i$. e by the year 2030. The method used in this process is trend extrapolation.

Our calculations predict relatively large positive or negative changes in the future use of land. Different degree of changes can be seen among different arable crops. The usage of agricultural land shows negative changes in every category on regional level.

Key words: Eastern region, agricultural land, trend analysis.

JEL: $Q 01, Q 15$

\section{Introduction}

Total surface area of Republic of Macedonia is $25,713 \mathrm{~km}^{2}$. Out of that, $1.9 \%$ is water and the rest is land. Its land area has most diverse geomorphologic terrain structure. According to Markovski (2004), lowland area takes 20.3\% (5,064.7 $\left.\mathrm{km}^{2}\right)$, highland area $30.5 \%\left(7,598.6 \mathrm{~km}^{2}\right)$ while the remaining $49.2 \%$ are mountains. This categorizes Republic of Macedonia as mountainous country.

In December 2007, Government of the Republic of Macedonia adopted the Nomenclature of Territorial Units for Statistics - NTES ("Official Gazette of the Republic of Macedonia” No. 158/2007). NTES consists of 5 levels: NTES level 1 and NTES level 2 represent the whole territory of the Republic of Macedonia as an administrative unit, NTES level 3 consists of 8 non-administrative units - statistical

1 Mile Peshevski, PhD, Full Professor, University "Ss Kiril and Methodius" in Skopje, Faculty of Agricultural Sciences and Food, Bvld. Aleksandar Makedonski bb, 1000 Skopje, Macedonia, Phone :+389 702436 16, e-mail: mile.pesevski@yahoo.com

2 Zoran Milovancevic, Enterprise "MILOVANCEVIC" O.D., Topola, Republic of Serbia. Phone: +381 636477 83, e-mail: zoranmilovancevic@gmail.com

EP 2017 (64) 4 (1437-1447) 
regions (Map 1) that are formed by grouping the municipalities as administrative units of lower level, NTES level 4 consists of 80 municipalities as administrative units, and NTES level 5 consists of 1,767 settlements.

Eastern region encompasses 11 municipalities: Berovo, Vinitsa, Delchevo, Zrnovtsi, Karbintsi, Kochani, Makedonska Kamenitsa, Pehchevo, Probishtip, Cheshinovo-Obleshevo and Shtip with 217 inhabited places. According to estimation from SSORM (2015c), on 30.06.2014 this area had 177,700 inhabitants, or $8.6 \%$ out of country's total population $(2,067,471$ inhabitants). Average population density in Macedonia is 83.0 inhabitants per $\mathrm{km}^{2}$, the lowest is in Pelagonia region (49.1 inhabitants $/ \mathrm{km}^{2}$ ) and the highest in Skopje region (339.7 citizens $/ \mathrm{km}^{2}$ ). In Eastern region population density is 50.2 inhabitants $/ \mathrm{km}^{2}$.

Map 1. Regions in the Republic of Macedonia

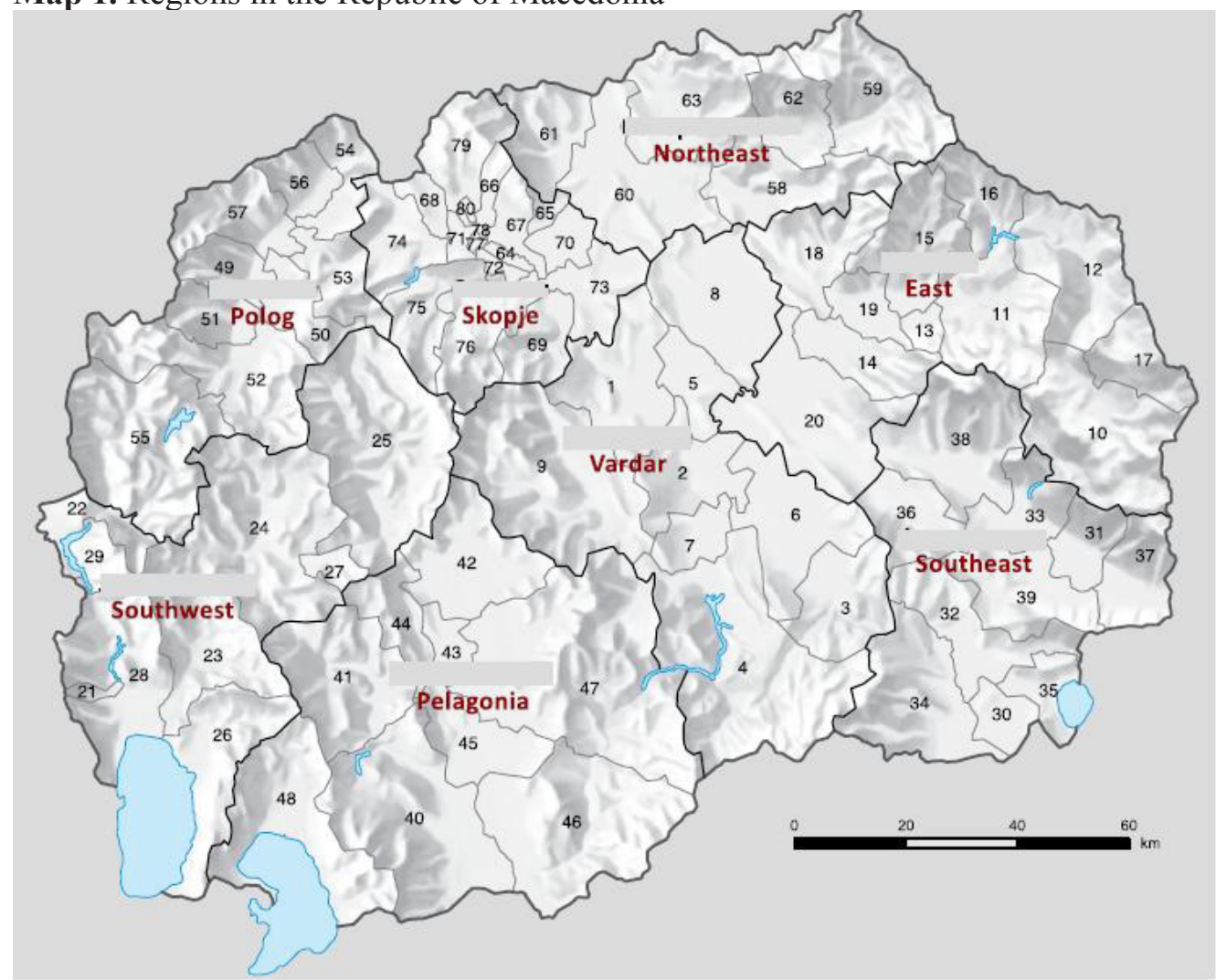

Sources: SSORM (2015a)

According to the data from SSORM (2014b) for added gross value in agriculture on country's level for 5 years (2009-2013), the South-East region had the biggest share of $30.3 \%$, followed by the Pelagonia region with $20.0 \%$, while the South-West region had the smallest share $-3.8 \%$. Eastern region had 8.0\% share. The South-East region had dominant share in total value of crop output in the Republic of Macedonia with 34.9\%, while Eastern region had $8.6 \%$. While the Pelagonia region was the largest contributor 
to the total value of animal output with $20.3 \%$, Eastern region contributed with $11.6 \%$. When it comes to vegetable output, the largest value (above 50\%) was produced in vegetables, then fruits (14.6\%), crops $(12.4 \%)$ and the last are vineyards (through wine production) with only $4.9 \%$ share in total value (average: 862.9 mil. EUR).

During previous years (2009 - 2012) there was an increase of total investments in basic funds. They grew from 1,331.2 mil. EUR in 2009 to 1,714.5 mil. EUR in 2012, i.e. $28.8 \%$ (SSORM, 2015c). The most resources (60.5\%) from these funds (average of 91,243 million MKD) were invested in Skopje region, while Eastern region got only $6 \%$. Relatively small investments were made into agriculture, forestry and fishery only 3\% of total investments (average of 2,465 million MKD). Unlike the increase of investments in total, here we can see the decline of investments, from 3,123 million MKD in 2009 to 2,221 million MKD in 2012. On the other side, the most resources from these funds were invested in Pelagonia region, while Eastern region got $9 \%$ of total investments. Although investments are small, agriculture nevertheless has relatively high share in country's GDP. For last 13 years (2000 - 2012) its share was $10.1 \%$ on average, varying between $8.9 \%$ in 2007 and $11.6 \%$ in 2004 (SSORM, 2015a).

In the Republic of Macedonia, agriculture has significant role which is supported by the fact that in 2014, over 49\% $(1,263,155$ ha) out of total surface area was used for agriculture production (SSORM, 2015a).

The highest percentage (20.8\%) of agricultural land is in Pelagonia region and the lowest in Skopje region - 6.3\% out of total agricultural land. Eastern region had 14\% share in total agricultural land area. The initial analysis of usage of agricultural land showed that this share is decreasing each year. The reasons for this are residential development, infrastructure facilities etc. but also emigration from rural areas.

The goal of this paper is to determine the degree of changes in usage of agricultural land in Eastern region for previous years (1991 - 2013). After that, we will present the prediction for development in agricultural land for following period (by 2030) on the basis of these changes.

\section{Materials and Methods}

To realize established goal, we used secondary data published by State Statistical Office of the Republic of Macedonia (SSORM) in Statistical review: Field crops, orchards and vineyards. Starting year is 1991 - that is the year when Republic of Macedonia gained independency and left former Yugoslavic Republic - and the final year is 2013. We believe that this period of 23 years is good enough base to predict future trends for agricultural land development. Trend analysis is a mathematical technique often used to predict future events. This analysis helps to determine if the values generally increase or decrease (getting "better" or "worse"). In statistical terms this is a determination of whether the probability distribution from which they arise has changed over time. Trend analysis is a special case of regression analysis where the dependent variable is the variable to be forecasted and the independent variable is time. 
Equation for a trend line, $\mathrm{F}=\mathrm{a}+\mathrm{bt}$

Where: $\mathrm{F}$ - forecast, $\mathrm{t}$ - time value, $\mathrm{a}$ - y intercept, $\mathrm{b}$ - slope of the line $\mathrm{b}=(\mathrm{n} \Sigma \mathrm{XY}-\Sigma \mathrm{X} \Sigma \mathrm{Y}) /\left[\mathrm{n} \Sigma \mathrm{X}^{2}-(\Sigma \mathrm{X})^{2}\right]$

This equation describes a straight line, $\mathrm{Y}$ represents area and $\mathrm{X}$ represents time. Linear regression is slow to recognize turning points and step function shifts in land use. Linear regression fits a straight line to the data, even when the data is seasonal or better described by a curve. Forecast specifications: $n$ equals the periods of history of land use that will be used in calculating the values for $a$ and $b$.

During this research, we used several statistical methods, common for these king of research. The information was analyzed with the help of MS-Excel (2013).

\section{Results and discussion}

\section{The usage of agricultural land from 1991 to 2013}

The terrain in Eastern region $\left(3,566.7 \mathrm{~km}^{2}\right)$ varies from lowland $(26,9 \%)$ to highland area with hills 200-500 AMSL. According to Markovski (2004), out of total area, $2.300,12 \mathrm{~km}^{2}$ is lowland terrain (500-1000 AMSL) and 233,07 $\mathrm{km}^{2}$ is low mountain area (1000-2000 AMSL).

The terrain, according to Panov (1998), is vertically placed between 225 AMSL and 1.130 AMSL. The lowest point is cadastral municipality Cheshinovo (municipality Cheshinovo-Obleshevo). Agricultural land in cadastral municipality Zelengrad (municipality Probishtip) is on the highest point and also the area where the Eastern mountain region is. However, the Eastern region area has relatively large natural resources for agricultural production. Namely, over $51 \%$ of area is agricultural land and over $50 \%$ of that land is cultivated (Table 1). Unfortunately, distribution of land for pasturage is almost the same as for cultivation. If you add the meadow area into this correlation, then the production of crops (hay) grows to $54.5 \%$ of agricultural land. This presents good basis for livestock farming, especially for cattle, sheep and goat farming. The analysis of this category of land per municipality showed that the highest prospects for developing milk production by increasing the number of dairy animals (cows, sheep and goats) have Berovo, Shtip and Kochani municipality and the lowest Zrnovtsi municipality. 
Table 1. Agricultural area by category of usage, 1991-2013 by municipalities

\begin{tabular}{|c|c|c|c|c|c|c|c|}
\hline \multirow{2}{*}{ Muncipalities } & \multirow{2}{*}{ Agricultural land } & \multicolumn{5}{|c|}{ Cultivated land } & \multirow{2}{*}{ Pastures } \\
\hline & & Total & Arable lend and gardens & Orchards & Vineyards & Meadows & \\
\hline Berovo & 37204 & 14619 & 9249 & 1173 & 0 & 4197 & 22583 \\
\hline Vinitsa & 15416 & 8322 & 7118 & 273 & 286 & 645 & 7093 \\
\hline Delchevo & 22679 & 12534 & 10199 & 801 & 9 & 1526 & 9708 \\
\hline Zrnovtsi & 1585 & 1514 & 1441 & 35 & 29 & 8 & 70 \\
\hline Karbintsi & 7860 & 7161 & 6549 & 159 & 342 & 111 & 700 \\
\hline Kochani & 25293 & 9968 & 9239 & 204 & 280 & 245 & 15327 \\
\hline Makedonska Kamenitsa & 4752 & 3542 & 3162 & 118 & 0 & 261 & 1210 \\
\hline Pehchevo & 8060 & 5047 & 3094 & 512 & 0 & 1441 & 3013 \\
\hline Probishtip & 18483 & 9379 & 8436 & 128 & 263 & 552 & 9100 \\
\hline Cheshinovo-Obleshevo & 7434 & 6468 & 6145 & 87 & 154 & 82 & 960 \\
\hline Shtip & 34762 & 13842 & 12740 & 201 & 732 & 212 & 20903 \\
\hline Total ER* & 183528 & 92396 & 77372 & 3691 & 2095 & 9280 & 90667 \\
\hline Total RM** & 1234160 & 585999 & 485649 & 16756 & 26806 & 56788 & 648161 \\
\hline Participation ER in RM(\%) & 14,9 & 15,8 & 15,9 & 23,6 & 7,8 & 16,3 & 14,0 \\
\hline
\end{tabular}

*Eastern Region

** Republic of Macedonia

Sources: SSORM (2014a)

The analysis of usage of agricultural land for previous years $(1991-2013)$ showed that it has relatively large oscillations from year to year. These yearly oscillations in usage of agricultural land are the most evident for pasture land, while other categories are more stable. The intensity of yearly oscillations in usage per municipalities is different. The Chart 1 shows example for Berovo municipality, the largest one in Eastern region, and its volume of agricultural land. During researched period (1991 - 2013), the agricultural land in Berovo municipality varied between 25,784 ha (2007) and 44,713 ha (1993), or the interval of 18,529 ha and $\mathrm{Cv}=16.8 \%$. The meadow area had relatively stable movement $(\mathrm{Cv}=13.6 \%)$. On the other side, big oscillations from average value can be seen for orchards $(\mathrm{Stdev}=502 \mathrm{ha} ; \mathrm{Cv}=42.8 \%)$. Here, maximum was 2,132 ha (1991), and minimum was in 2006 (583 ha), after which the area grew again to 1,216 ha in 2013. 
Chart 1. The dynamics of usage of agricultural land in Berovo municipality

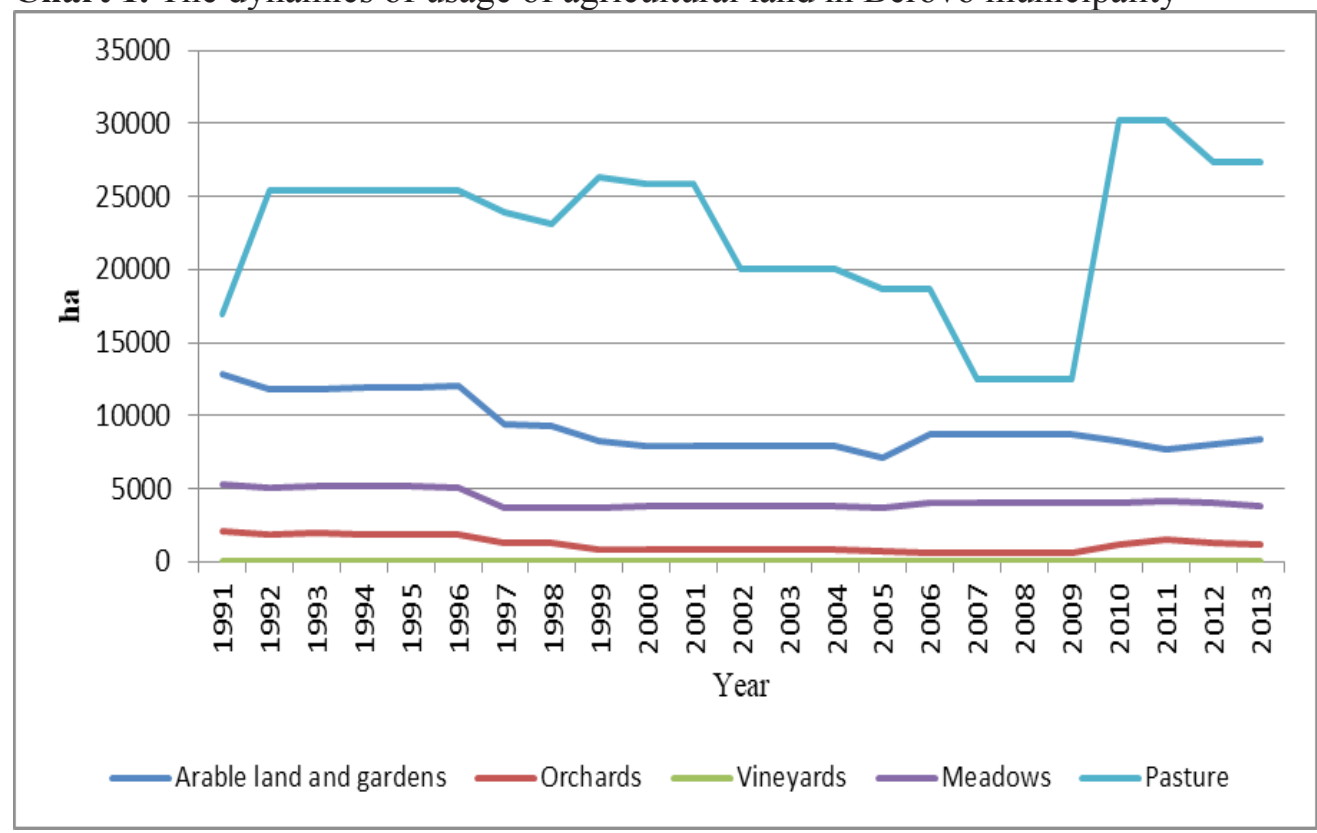

Sources: SSORM (1992-2014) and personal calculations

The arable land and gardens can be seen mostly in Sthip, Delchevo, Berovo and Kochani area and rarely in Zrnovtsi municipality. This means that the first four municipalities have the best prepositions for development of vegetable, industrial and pasturage (annual and perennial) arable crops, unlike the last municipality.

\section{Changes in usage of land for agricultural production}

The agricultural production mainly takes place in gardens, arable land, meadows and pastures. But in practice there are cases where perennial crops are uprooted. This happens when the plantation is amortised. For a year or two after, instead of new plantation, annual or bi-annual agricultural crops are planted. There are also situations when orchards and vineyards are cultivated on arable land, gardens, meadows or pasturage areas.

In any case, Eastern region has plenty annual crops. However, State Statistical Office doesn't evident every crop area but only those areas larger than 0.1 ha. Because of that, the statistical evaluation is missing 28,516 ha, that is - data encompasses only 145,803 ha out of 174,319 ha in total (Table 1). This is the reason why our research encompassed only 28 crops. 
Table 2. The changes in crop areas (ha)

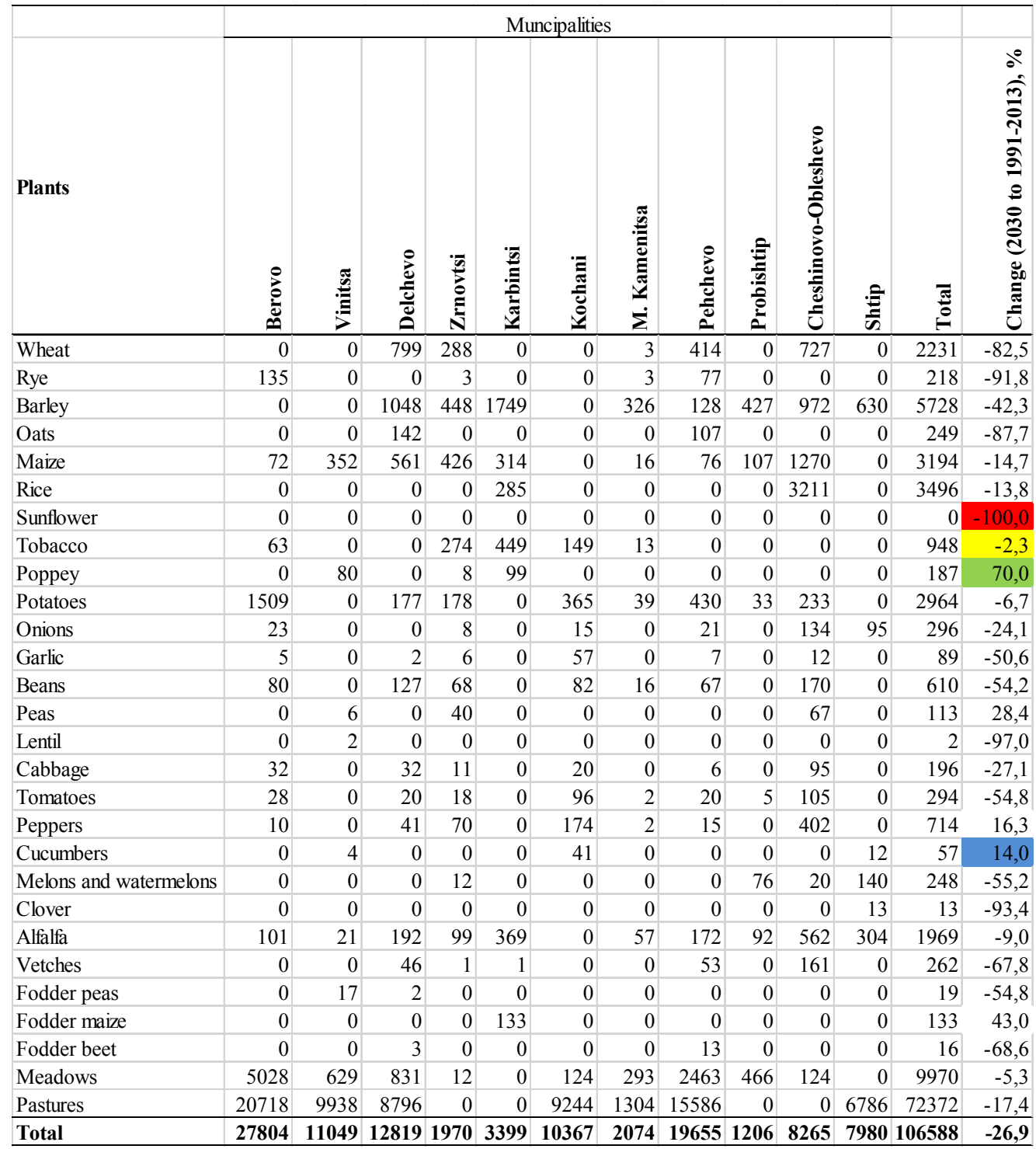

Sources: Personal calculations

The analysis of data for last 23 years showed that every crop area has relatively high oscillations in volume of land used for its cultivation respectively. The intensity of oscillations has positive or negative impact on trend for following period by 2030. Unfortunately, for large number of arable cultures, negative impact is more expressed than positive one (Table 2). By 2030, in Eastern region the area that had been used for crops production (1991 2013) will decrease for 39,215 ha, or $26.9 \%$. The results from the trend analysis showed that by 2030 , there will be no sunflower production. There will be almost no rye, lentil or alfalfa. The smallest decrease is expected for tobacco (only $-2.3 \%$ ). On the other hand, $70 \%$ 
increase can be expected for poppy, $43 \%$ for feed grain etc.

In the next part of this paper we will give an example of changes in area for potato production. In Eastern region during the previous period, potato production used average land area of 2,988 ha, or $22.2 \%$ of total land area in the country. The largest area (28.7\%) was in Berovo municipality and the smallest (2.6\%) in Probishtip municipality.

During previous years there was an increase in land area for potato production that happened almost each year in Berovo municipality. Out of 700 ha in 1991, the total area increased to 1250 ha in 2013, while deviations from average value ( 859 ha) were $22 \%$. As a result of constant increase during researched period, the trend of positive changes will continue by year 2030 (Chart 2).

Chart 2. The projection for land area for potatoes production in Berovo municipality

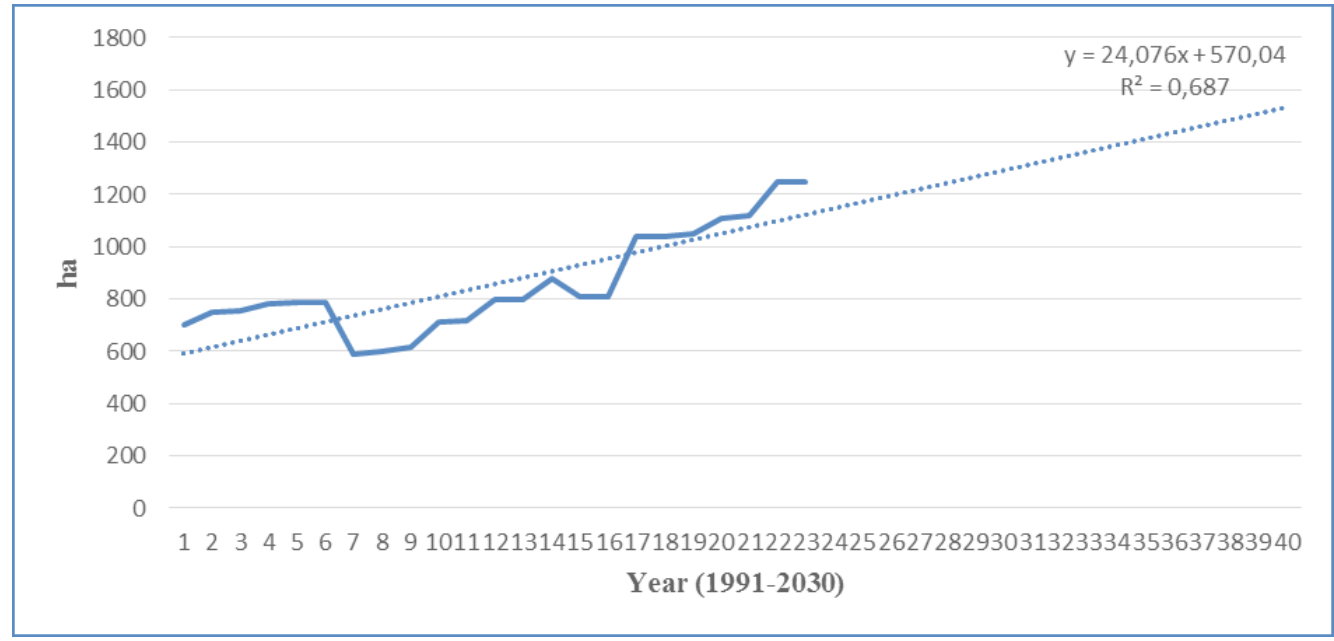

The land area for potato production in Berovo municipality grows every year for 24 ha. As a result, the total land area in 2020 will be 1,268 ha and by 2030 it will be 1,509 ha.

\section{The changes in usage of land for orchards and vineyards}

During the researched period (1991 - 2013) in Eastern region orchards were cultivated on 3,691 ha (Table 1) on average, or 22\% of total area in the Republic of Macedonia (SSORM, 2015a). But, according to information from statistical reviews (SSORM, 2014a), there is only 972.7 ha, or less than $19.5 \%$ orchards out of total land area. The difference of 718.3 ha is the result of the fact that SSO doesn't review orchards smaller than 0.1 ha.

However, during previous time period there can be seen positive tendency in changes for large number of fruit varieties. Consequently, the same varieties will continue this growing trend for the following period until 2030 on regional level (Table 3). Other fruits on municipal level will disappear. The largest negative changes on regional level will happen for pears, and the least for plums. On the other hand, the largest positive changes will happen for cherries and the least for sour cherries. 
Table 3. The changes for orchards and vineyards areas (ha)

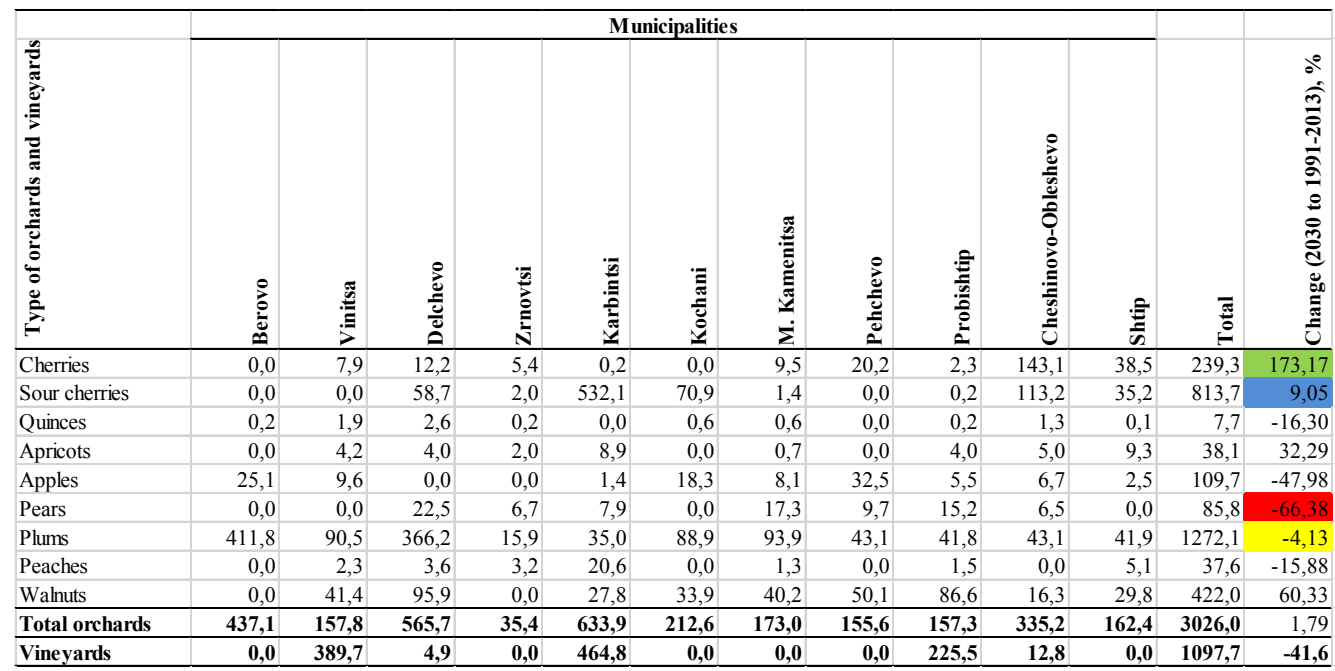

Sources: Personal calculations

The average size of land used for plums production during last period in Berovo municipality was 390.8 ha which coincides with 128,975 trees. For future years, on regional level, the highest increase in size of land used for plums production will happen in Berovo municipality (Chart 3). Yearly increase will amount to average of 0.8 ha. Total land area by 2020 will be 404 ha, and in 2030, 411.8 ha which is related to increase of $5.4 \%$.

The research showed that for the last 23 years vineyards in Eastern region grew on $1,880.4$ ha on average, with 2,732 trees per hectare on average. In the following period, there will be continuous decrease in size of the land used for vineyards. By 2030, there will be $1,097.7$ ha, or $41.6 \%$ less than average size of the land used for vineyards. 
Chart 3. The projection for land area for plum production in Berovo

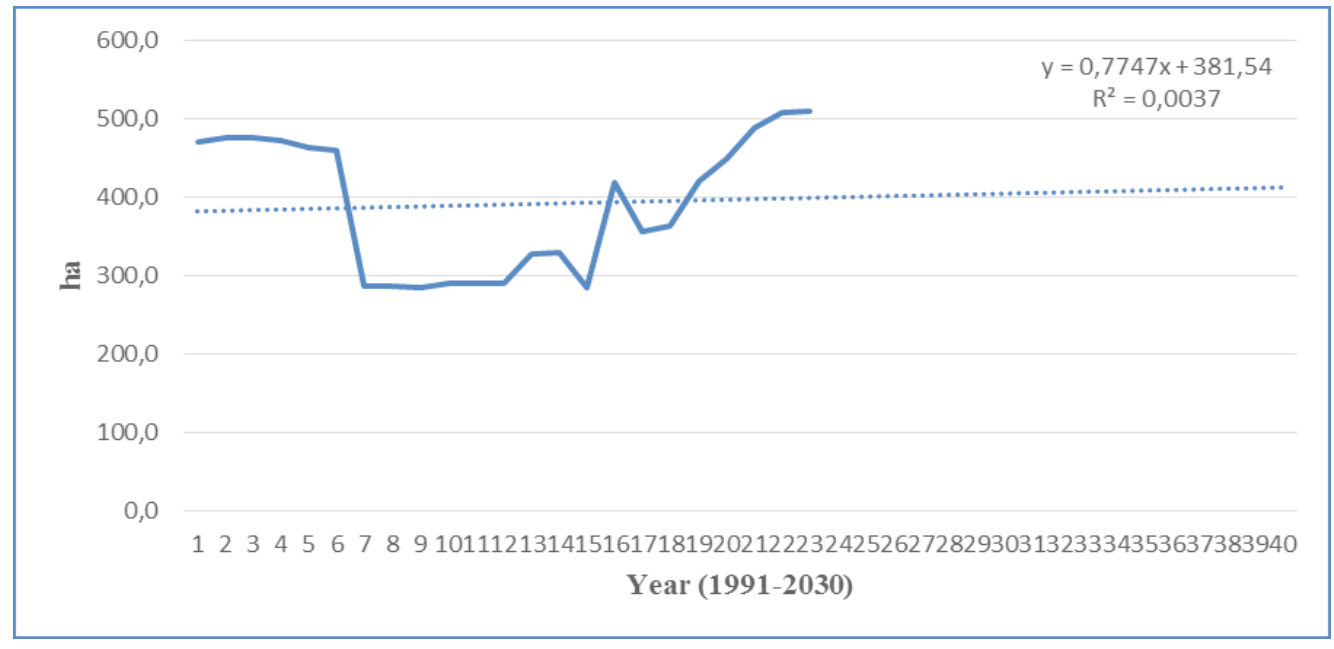

The largest size of land used for vineyard cultivation in Eastern region will be in Karbintsi municipality. Karbintsi municipality, which was part of Shtip municipality until 1997, will have dominant share in total land area used for vineyards in Eastern region (42.3\%). Here, the land size used for vineyards will be increasing by 5.2 ha until it reaches 464.8 ha in 2030 (Chart 4).

\section{Conclusion}

Due to the methodological reasons, Eastern region and the rest of the country, has differences in land surfaces which are presented according to the category of usage (Table 1) along with those land surfaces that are presented as land per arable crop (Table 2 and 3). Consequently, the land surface used for crop and vegetable production is $37.8 \%$ larger than the area categorized as arable land and gardens, while orchards are $18 \%$ and vineyards $47.6 \%$ smaller. Because of that, the calculations for trend development were made only for those arable crops that have available statistical data.

The degree of yearly changes in the land surfaces for the last period has deciding role in calculations for the following period until 2030. Due to that, different degree of changes can be seen for different arable crops. The research has shown that the least negative change will affect tobacco areas $(-2.3 \%)$, while the most negative change will affect sunflower $(-100 \%)$. On the other hand, by the year 2030 the area for cucumber production will be 14\% larger and for poppy production $70 \%$ larger. In fruit production, the biggest decrease in land area by the year 2030 will affect pear production $(66.4 \%)$ and the least for plum production (4.1\%). In the same time, the most positive changes will happen for cherry (173.1\%) and the least positive (9\%) for sour cherry production. By 2030., the average land area for vineyards will be almost $42 \%$ smaller than the average area for vineyards between 1991 and 2013. 
Chart 4. The projection for land used for vineyards in Karbintsi

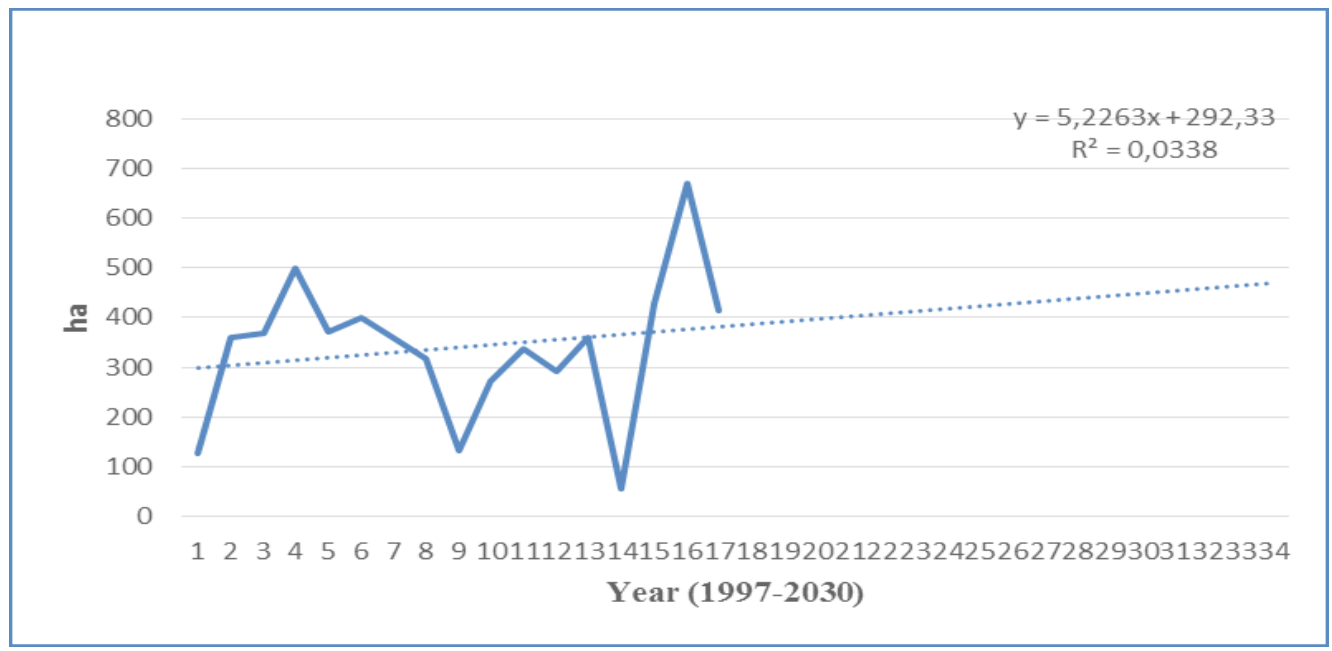

\section{References}

1. Markovski B. (2004): Kartografsko definiranje i definiranje na planinskite prostorni celini vo Republika Makedonija. Bilten na Zavodot za fizichka geografija (01) 2534, Skopje.

2. Panov M. (1998): Enciklopedija na selata vo Republika Makedonija-geografski, demografski i agrarni obelezja. Napredok, Tetovo.

3. SSORM (2014a): Statistical review: Field crops, orchards and vineyards, 19912013, Skopje.

4. SSORM (2014b): Agriculture, New Release: Regional accounts for Agriculture, 2009-2013, Skopje.

5. SSORM (2015a): Statistical yearbook of the Republic of Macedonia, 1992-2015. Skopje.

6. SSORM (2015b): Statistical review: Population and Social Statistics, Skopje.

7. SSORM (2015c): Regions of the Republic of Macedonia, 2009-2015, Skopje.

8. Government of the Republic of Macedonia (2004). Spatial plan of the Republic of Macedonia, Skopje 
ECONOMICS OF

AGRICULTURE

\section{CONTENT}

1. Adriana Radosavac, Desimir Knežević

ECONOMIC IMPORTANCE OF USE

OF PESTICIDES IN WHEAT PRODUCTION . . . . . . . . . . . 1323

2. Berhe Gebregewergs, Muuz Hadush

DOES CLIMATE CHANGE AFFECT PRICE OF VEGETABLES:

EVIDENCE FROM TIGRAI, NORTHERN MOST ETHIOPIA. . . . .1335

3. Grujica Vico, Aleksandra Govedarica-Lučić, Zoran Rajić, Radomir Bodiroga, Ivan Mičić, Silvija Zec Sambol, Marija Mičić

MULTI ATTRIBUTE ASSESSMENT APPROACH

IN VEGETABLE PRODUCTION . . . . . . . . . . . . . . 1355

4. Igor Trandafilović, Vesna Conić, Aleksandra Blagojević

IMPACT OF DEMOGRAPHIC FACTORS ON

ENVIRONMENTALLY CONSCIOUS PURCHASE BEHAVIOUR. . .1365

5. Imre Milán Harcsa

STUDY ON THE POTENTIAL OF SUBCONTRACT

PALINKA DISTILLATION . . . . . . . . . . . . . . 1379

6. Jelena Andrašić, Vera Mirović, Nada Milenković, Branimir Kalaš, Miloš Pjanić

IMPACT OF TAKEOVER PROCESS ON EMPLOYEES -

EVIDENCE FROM FOOD, RETAIL AND FINANCIAL SECTOR . . .1393

7. Jelena Birovljev, Danilo Đokić, Bojan Matkovski, Žana Kleut

ECONOMIC PERFORMANCES OF AGRICULTURE

OF CEFTA AND FORMER CEFTA COUNTRIES . . . . . . . . . . 1413

8. Jelena Marković, Svetlana Stevović

SUSTAINABILITY OF CHEMICAL SOIL QUALITY

IN SOUTHERN MORAVA RIVER VALLEY

IN CORELLATION WITH THE FLOODING $\ldots \ldots \ldots \ldots \ldots$ 
9. Mile Peševski, Zoran Milovančević

THE CHANGES IN THE USAGE OF AGRICULTURAL LAND

IN EASTERN REGION OF REPUBLIC OF MACEDONIA

BETWEEN $1991-2030 \ldots \ldots$. . . . . . . . . . . . . . . . . . . . . . .

10. Odjuvwuederhie Emmanuel Inoni, 'Oraye Dicta Ogisi, Felix Odemero Achoja

PROFITABILITY AND TECHNICAL EFFICIENCY IN HOMESTEAD

CATFISH PRODUCTION IN DELTA STATE, NIGERIA . . . . . . . 1449

11. Olja Munitlak - Ivanović, Jovan Zubović, Petar Mitić

RELATIONSHIP BETWEEN SUSTAINABLE DEVELOPMENT AND

GREEN ECONOMY - EMPHASIS ON GREEN FINANCE

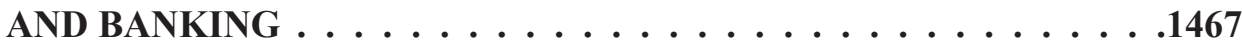

12. Petar Munćan, Dragica Božić

FARM SIZE AS A FACTOR OF EMLOYMENT AND INCOME

OF MEMBERS OF FAMILY FARMS . . . . . . . . . . . . . 1483

13. Rade Popović, Mira Kovljenić

EFFICIENCY OF WHEAT PRODUCTION ON FARMS

IN THE REPUBLIC OF SERBIA . . . . . . . . . . . . . . . . . . . . . . . . .

14. Radovan Damnjanović, Snežana Krstić, Milena Knežević, Svetislav Stanković,

Dejan Jeremić

THE DISCRIMINANT ANALYSIS APPLIED TO THE

DIFFERENTIATION OF SOIL TYPES . . . . . . . . . . . . 1513

15. Slavica Otović, Dunja Demirović, Kristina Košić, Aleksandra Vujko

FOSTERING ENTERPRENUERSHIP AT HIGH SCHOOLS:

A CASE OF RURAL AREAS IN VOJVODINA (SERBIA) . . . . . . .1523

16. Vladimir Ilić, Ivan Bauer, Anastazija Tanja Đelić, Aleksandar Nešković

INSTITUTIONAL SUPPORT FOR STRENGTHENING

ENTREPRENEURSHIP IN AGRICULTURAL PRODUCTION

OF THE REPUBLIC OF SERBIA . . . . . . . . . . . . . . . . . . . . . . . .

17. Boro Krstić, Zorica Vasiljević, Miroslav Nedeljković

INSURANCE CONTRACT AS THE BASIS FOR THE SAFETY OF

AGRICULTURAL PRODUCERS IN THE REPUBLIC OF SRPSKA • . 1555

18. Dejan Sekulić, Aleksandar Petrović, Vladimir Dimitrijević

WHO ARE WINE TOURISTS? AN EMPIRICAL INVESTIGATION

OF SEGMENTS IN SERBIAN WINE TOURISM . . . . . . . . . . . . . 
19. Milan Beslać, Ćorić Goran

FINANCIAL AND PRODUCTION ASPECTS OF GENETICALLY MODIFIED ORGANISMS $\ldots \ldots \ldots \ldots \ldots \ldots \ldots \ldots \ldots$

20. Mlađan Maksimović, Darjan Karabašević, Miodrag Brzaković, Pavle Brzaković THE EFFECTS RESULTING FROM THE APPLICATION OF THE CONCEPT OF THE SUSTAINABLE DEVELOPMENT OF RURAL TOURISM ON STARA PLANINA . . . . . . . . . . . . . . . .1595

21. Vesna Popović, Predrag Vuković, Milivoje Ćosić FOOD SAFETY AND QUALITY POLICY IN THE REPUBLIC OF SERBIA . . . . . . . . . . . . . . . . 1607

22. Radovan Pejanović, Danica Glavaš-Trbić, Mirela Tomaš-Simin PROBLEMS OF AGRICULTURAL AND RURAL DEVELOPMENT IN SERBIA AND NECESSITY OF NEW AGRICULTURAL POLICY . . . .1619

23. Saša Marković, Slavoljub Vujović, Aleksandar Damnjanović MARKETING AND HIGHER EDUCATION CONDITION IN SERBIA . . . . . . . . . . . . . . . . 1635

24. Semir Vehapi, Marina Milanović THE EFFECT OF MARKET ORIENTATION ON BUSINESS PERFORMANCE OF SERBIAN ORGANIC PRODUCERS . . . . . 1651

25. Suad Bećirović, Šemsudin Plojović, Enis Ujkanović, Senadin Plojović CHALLENGES AT STARTING AN AGRIBUSINESS IN THE HILLY MOUNTAINOUS REGIONS OF SOUTHWEST SERBIA . . . . . . . .1669

26. Vladimir Zakić, Vlado Kovačević, Jelena Damnjanović SIGNIFICANCE OF FINACIAL LITERACY FOR THE AGRICULTURAL HOLDINGS IN SERBIA . . . . . . . . . . 1687

27. Željko Bjelajac, Marijana Dukić Mijatović, Željko Vojinović PROTECTION OF LAND IN THE REPUBLIC OF SERBIA AND ECOLOGICAL SECURITY WITH REGARD TO STRATEGIC AND LEGAL FRAMEWORKS . . . . . . . . . .1703 